\title{
Rewitalizacja a jakość przestrzeni publicznej centrum miasta
}

\section{Anna Wojnarowska}

\begin{abstract}
STRESZCZENIE
Celem niniejszego artykułu jest przedstawienie wyników badań przeprowadzonych na podstawie autorskiej metody oceny jakości przestrzeni publicznej centrum miasta, wykazujących związek pomiędzy jakością przestrzeni publicznej centrum a procesem rewitalizacji tej strefy miasta. Jakość przestrzeni miejskiej ma współcześnie istotne znaczenie zarówno dla jakości życia mieszkańców, jak i atrakcyjności miasta dla użytkowników zewnętrznych i inwestorów. Przestrzeń publiczna rozumiana jako przestrzeń otwarta o ogólnej dostępności pełni ważne funkcje społeczne, kulturalne, gospodarcze, rekreacyjne i turystyczne, jest nośnikiem tożsamości miasta, a także buduje jego wizerunek i jest czynnikiem identyfikacji dla mieszkańców. W związku z tak ważną rolą przestrzeni publicznej, szczególnie usytuowanej w centrum miasta, zasadnicze znaczenie ma jej wysoka jakość. Aby określić jakość przestrzeni publicznej centrum miasta opracowano autorską metodę oceny, składającą się z trzech elementów: waloryzacji graficznej, waloryzacji tabelarycznej i badań kwestionariuszowych. Metoda ta umożliwia ocenę jakości istniejącej przestrzeni publicznej, ale może stanowić też istotną przesłankę w projektowaniu przestrzeni publicznej oraz programowaniu inwestycji i działań w niej zachodzących. Rewitalizacja centrum miasta stanowić może ważny instrument poprawy jakości przestrzeni publicznej, w przypadku właściwie zaprogramowanego procesu rewitalizacji, uwzględniającego istotne czynniki jakości przestrzeni publicznej, rzutujące na: witalność, spełnianie potrzeb, dostępność, kompozycję i czytelność, bezpieczeństwo oraz spełnianie zasad zrównoważonego rozwoju. Badania przeprowadzone na grupie sześciu wybranych miast średnich regionu łódzkiego wykazały zależność pomiędzy wysoką jakością przestrzeni publicznej miasta a rewitalizacją jego centrum.
\end{abstract}

Współcześnie w rozwoju miejskim coraz większą rolę zaczynają odgrywać aspekty jakościowe, nie tylko ilościowe. Teorie ekonomiczne dotyczące czynników lokalizacji oraz koncepcje konkurencyjności miast wskazuja że to właśnie czynniki jakościowe, a wśród nich szeroko rozumiana jakość przestrzeni miejskiej, mają coraz większe znaczenie w podejmowaniu decyzji lokalizacyjnych przez inwestorów oraz nowych mieszkańców. Miasta, w celu budowania swojej atrakcyjności, starają się wzmocnić i ulepszyć ofertę, która w przypadku elementów przestrzeni miejskiej nie tylko obejmuje jej funkcjonalność, ale też wyjątkową urodę, niepowtarzalną tożsamość oraz zdolność do tworzenia wysokiej jakości warunków zamieszkania, pracy i wypoczynku. Centra miast i istniejąca tam przestrzeń publiczna mają szczególne znaczenie dla jakości przestrzeni miast i ich atrakcyjności - jako fragment miasta najczęściej odwiedzany i najbardziej znany dla użytkowników z zewnątrz oraz element identyfikacji dla mieszkańców. Władze lokalne podejmują rewitalizację stref centralnych miast, w tym zlokalizowanej tam przestrzeni publicznej, zmierzając do podniesienia jej jakości. Należy jednak stwierdzić, że brakuje ustalonych kryteriów, jakimi należałoby się kierować przy planowaniu działań mających na celu wzrost jakości przestrzeni publicznej centrum, aby uzyskać nie tylko poprawę jej walorów funkcjonalnych, estetyki i stanu technicznego, ale też osiągnąć szersze efekty, jak ożywienie centrum i przyciągnięcie doń użytkowników. Istotne jest także stworzenie atrakcyjnego środowiska zamieszkania i rekreacji dla mieszkańców tego rejonu miasta. 
Kwestia zapewnienia żywotności centrum miasta jest obecnie jednym z często dyskutowanych problemów rozwoju miejskiego, w sytuacji, kiedy pojawiają się obawy dotyczące jego przyszłości, a na naszych oczach centra miast tracą swoje kolejne tradycyjnie utrwalone funkcje. Pojawiają się hasła „powrotu do centrum” lub szersze „powrotu do miasta”, będące reakcją na ucieczkę mieszkańców ze stref centralnych do obrzeżnych i obszarów pozamiejskich. Dyskutowane są warunki konieczne do realizacji tych haseł, przede wszystkim dotyczące potrzeby podniesienia jakości życia w centrum w takim zakresie, aby móc pozyskać nowych mieszkańców i użytkowników. Rewitalizacja centrum miasta nie zawsze przynosi oczekiwane efekty, często ograniczając się do pozytywnych przemian substancji fizycznej, a nie wywołując pozytywnych skutków społecznych i gospodarczych. Należy w tym miejscu zaznaczyć, że artykuł dotyczy przypadków rewitalizacji centrów miast zrealizowanych w okresie przed wejściem w życie Ustawy o rewitalizacji [2015], co oznacza że używane pojęcia związane z rewitalizacją oraz zakres programów rewitalizacji wywodzą się z wcześniejszych regulacji związanych z procesami rewitalizacji w Polsce.

Celem niniejszego artykułu jest przedstawienie wyników badań przeprowadzonych na podstawie autorskiej metody oceny jakości przestrzeni publicznej centrum miasta, wykazujących związek pomiędzy jakością przestrzeni publicznej centrum a procesem rewitalizacji tej strefy miasta.

\section{Centrum miasta, przestrzeń publiczna, jakość przestrzeni publicznej}

Centrum w całym przebiegu historii rozwoju miasta europejskiego stanowiło jego nieodłączny i najważniejszy pod względem przestrzennym, funkcjonalnym i prestiżowym element. Nie jest znany żaden projekt miasta idealnego, ani też żaden rzeczywisty przykład istnienia miasta pozbawionego centrum [Parysek, Guarino, Mierzejewska 1995, s. 31]. Tutaj zlokalizowane były reprezentacyjne obiekty stanowiące siedzibę władz, kultu religijnego oraz pełniące ważne funkcje kulturalne, religijne, usługowe i rozrywkowe [Chmielewski 2001, s. 253]. Centrum ogólnomiejskie było zawsze elementem struktury miejskiej pod względem obszaru stosunkowo niedużym, o centralnym położeniu, wyróżniającym się kompozycją urbanistyczną i wartościami architektonicznymi [Juchnowicz 1971, s. 5; Wallis 1979, s. 19]. Charakteryzowało się też największą w mieście koncentracją i unikatowością funkcji, intensywnością zabudowy, wartością estetyczną i historyczną obiektów oraz maksymalną dostępnością, decydującymi o jego atrakcyjności, a co się z tym bezpośrednio wiąże - atrakcyjności całego miasta [Górka 1986, s. 9]. Należy też podkreślić, że centrum to nie tylko najintensywniej zabudowany obszar miasta, ale też skupisko najsilniejszych aktywności [Maliszowa 1974].

Centrum miasta, tak jak i samo miasto, można traktować jako system, który składa się z podsystemu społecznego i podsystemu urbanistycznego [Wallis 1979, s. 5]. Jest ono kategorią nie tylko przestrzenna, ale stanowi efekt procesu społecznej organizacji przestrzeni miejskiej: „Centrum miasta, podobnie jak całe miasto jest wytwarzane, wyraża więc działające siły społeczne i strukturę ich wewnętrznej dynamiki" [Castells 1982, s. 235]. Centrum 
ma ważny wymiar społeczny jako miejsce, w którym zachodzą najistotniejsze dla społeczności miejskiej procesy informacyjne, prawne, polityczne, kulturowe, ideologiczne i światopoglądowe [Wallis 1979, s. 7]. Centrum jest najbardziej rozległym, zróżnicowanym i skomplikowanym obszarem kulturowym, jaki wytworzyło społeczeństwo miejskie [Wallis 1979, s.18], jest też „z reguły identyfikowane z najważniejsza czéścia miasta, z ośrodkiem miejskiego życia i obszarem największej atrakcyjności" [Wallis 1977, s. 208]. Fragment miasta, które stanowi centrum, powinien zapewnić możliwość zaistnienia różnych form życia społecznego: miejsc zacisznych do odpoczynku i kontemplacji, ruchliwych ulic, placów handlowych i rozrywkowych oraz miejsc reprezentacji i prestiżu. Centrum miasta pełni też wyjątkową rolę w wytwarzaniu emocjonalnej więzi mieszkańców z miastem, stając się podstawowym elementem w procesie identyfikacji mieszkańców z miastem [Wallis 1977, s. 214]. Centrum w znaczeniu socjologicznym pełni jeszcze jedna, istotną dla społeczności miejską rolę: daje możliwość odczucia integracji z pozostałymi mieszkańcami, przy zachowaniu anonimowości, możliwość obserwacji i bycia widzianym [Nowakowski 1976, s. 13]. Centrum miasta odgrywa rolę symboliczną i integrującą w sensie społecznym, a zlokalizowane w nim funkcje są wykorzystywane przez największą liczbę użytkowników, przy czym ich przestrzenna bliskość nie odgrywa roli w korzystaniu z nich. Centrum jest także ośrodkiem działalności ludycznej, koncentracji rozrywek i stanowi sublimację klimatu miejskiego, mając ogromy walor przyciągania, dzięki bogatej gamie dostępnej oferty i dostępności do konsumpcji.

$\mathrm{Z}$ punktu widzenia funkcji centrum miasta to „ośrodek usługowy najwyższego stopnia $w$ danej jednostce lub zespole jednostek osadniczych, utworzony przez koncentrację obiektów głównie ustugowych $i$ dyspozycyjnych (w tym przede wszystkim handlu, gastronomii, rzemiosła, kultury, rozrywki i administracji), zwykle o charakterze unikatowym, położonych w rejonie głównego węzła komunikacyjnego danego układu osadniczego" [Nowakowski 1990, za: Chmielewski 2001, s. 258]. B. Maliszowa w swoich rozważaniach [Maliszowa 1974] podkreślała co najmniej ogólnomiejski, a często regionalny zasięg oddziaływania usług zlokalizowanych w centrum oraz jego położenie w miejscu zbiegu szlaków różnego rodzaju komunikacji.

Należy zwrócić uwagę na wielofunkcyjność centrum miasta, a także zanikanie pewnych funkcji oraz zmieniające się znaczenie i nasilanie funkcji pozostających, uzależnione od uwarunkowań obronnych, politycznych, ekonomicznych, społecznych i kulturowych. W przebiegu historii rozwoju miast możemy obserwować sukcesję funkcji w centrum: jedne funkcje zanikają w ich miejsce pojawiają się nowe [Wolaniuk 2008, s. 311-313].

Do niedawna, jako podstawową cechę przestrzeni publicznej, wymieniano publiczny charakter własności - gminny lub Skarbu Państwa, ostatnio obserwujemy odejście od takiej interpretacji. W Karcie Przestrzeni Publicznej z 2009 roku podkreśla się, że o publicznym charakterze przestrzeni decyduje zbiorowy sposób jej użytkowania i w takim ujęciu nie ma znaczenia stan własności przestrzeni. Podstawową cechą przestrzeni publicznej jest jej charakter terenu otwartego, dostępnego wszystkim użytkownikom, kształt przestrzenny jako wnętrza urbanistycznego oraz możliwość zaistnienia różnego rodzaju aktywności i interakcji [Gruszecka i in. 2009, s. 49]. Otwartość przestrzeni publicznej - w rozumieniu powszechnego 
korzystania i dostępu do niej - przejawia się w liczbie pełnionych przez dane miejsce funkcji, które wpływają bezpośrednio na różnorodność sposobów jej wykorzystywania [Cegłowska i Matykowski 2010, s. 244]. Ta właśnie cecha - ogólna dostępność - wydaje się w obecnej chwili podstawowa dla zdefiniowania przestrzeni publicznej. W przedstawianej pracy badawczej przyjęto, że miejska przestrzeń publiczna obejmuje wyłącznie miejskie przestrzenie otwarte [Wejchert 1984; Chmielewski 2001], a nie przestrzenie zamknięte w obiektach użyteczności publicznej [Lorens 2007; Mierzejewska 2011]. Natomiast egalitaryzm użytkowania przestrzeni publicznej manifestuje się w braku konieczności spełniania przez jednostkę dodatkowych warunków, narzuconych zewnętrznie [Habermas 2007; Kowalczyk 2009, za: Mierzejewska 2011, s. 86].

Przestrzeń publiczną możemy podzielić na dwie zasadnicze kategorie ze względu na pełnione przez nią role:

1. Przestrzeń publiczna o charakterze kulturowym - obejmuje obszary otwarte, w których wprowadzono świadomie ograniczenia komunikacyjne, dzięki czemu są one kształtowane dla ruchu pieszego i ewentualnie rowerowego, stanowiąc miejsce wydarzeń i kontaktów społecznych - bezpośredniej interakcji osób, która tworzy podstawy kształtowania się obyczajów i życia społecznego;

2. Przestrzeń publiczna o charakterze technicznym - obejmuje ulice, w których wymagania inżynierii ruchu przesądzają o formie urbanistycznej przestrzeni, a kontakty międzyludzkie są ograniczone [Gehl 2001, za: Chmielewski 2001, s. 204].

Obie te kategorie współtworzą system miejskiej przestrzeni publicznej i można stwierdzić, że poszczególne elementy tego systemu należą do kategorii pierwszej lub drugiej, ale często też należą do obu wyróżnionych kategorii, łącząc w sobie rolę techniczną i społeczno-kulturową.

Elementy systemu przestrzeni publicznej to przede wszystkim: ulice, aleje, place, skwery, bulwary, tereny zieleni miejskiej, ciągi piesze i pieszo-jezdne. Ale trzeba też zauważyć fundamentalną rolę w kształtowaniu przestrzeni publicznej sąsiadujących z nim obiektów i obszarów prywatnych i półpublicznych. Fakt ten został doceniony przez autorów Karty Przestrzeni Publicznej [2009], którzy uznali za przestrzeń publiczną wszystko, co współtworzy krajobraz, klimat i estetykę miasta, w tym elementy przyrody, zabudowy i zagospodarowania znajdujące się nie tylko na terenach publicznych, ale też poza nimi i w ich sąsiedztwie, o ile znajdują się w zasięgu postrzegania przebywających w przestrzeni publicznej ludzi [Mierzejewska 2011, s. 16]. O charakterze przestrzeni publicznych współdecyduje w związku z tym architektura otaczającej zabudowy, sposób użytkowania obiektów tworzących ściany tej przestrzeni oraz rodzaj zbiorowości tworzących i użytkujących zarówno przestrzeń publiczna, jak i otaczające obiekty i tereny [Lorens 2006, s. 15]. To one wpływają w istotnym stopniu, poza zagospodarowaniem samej przestrzeni publicznej, na jej odbiór, współtworząc wrażenia i budując unikatowy, niepowtarzalny charakter.

Jakość przestrzeni publicznej ma istotne znaczenie we wszystkich jej aspektach - przekłada się na wartość ekonomiczną lokalizacji [Kochanowski 2002, za: Lorens 2006, s. 27], a także na jakość życia mieszkańców i atrakcyjność miasta. Jakość przestrzeni publicznej 
musi przejawiać się w związku z tym nie tylko w estetyce przestrzeni, ale też w walorach użytkowych, środowiskowych, kulturowych, społecznych, gospodarczych oraz zachodzących w niej aktywnościach i interakcjach międzyludzkich. Właśnie aktywności występujące w przestrzeni publicznej, mogą być kryterium oceny jakości przestrzeni publicznej, ponieważ ich rodzaj i zaistnienie zależą od jej zdolności ich generowania. J. Gehl wyróżnia: „aktywności niezbędne”, czyli codzienne czynności, takie jak wyjście do sklepu po zakupy czy dojście do przystanku autobusowego, „aktywności opcjonalne”, mające szanse wystąpić w przypadku zaistnienia dogodnych warunków, jak spacer dla przyjemności oraz „aktywności społeczne", które są efektem ewoluowania z aktywności niezbędnych i opcjonalnych. Gehl uważa, że obecność „aktywności społecznych” stanowi o wysokiej jakości przestrzeni publicznej i może stanowić jedno z kryteriów jej oceny [Gehl 2001, s. 11-16, za: Szewczyk 2009, s. 78].

Centrum miasta w dużym stopniu zbudowane jest z przestrzeni publicznej, która skupia najważniejsze funkcje i wydarzenia w mieście, w zakresie życia społecznego, gospodarczego i kulturowego. Przestrzeń publiczna wyraża także tożsamość miasta w najbardziej wyrazisty sposób, a wysoka jakość przestrzeni publicznej centrum przekłada się na wzrost atrakcyjności centrum i miasta jako całości. Od wielu dekad w środowiskach profesjonalnych dyskutowane są czynniki wpływające na jakość przestrzeni publicznej [Lynch 1984; Carmona i Sieh 2004; CABE 2004; European Council of Spatial Planners 2005], jak i zagadnienia dotyczące zapewnienia żywotności miastom i ich centrom oraz bezpieczeństwa publicznego [Jacobs 1961; Whyte 1988; Crowe 2000]. Także koncepcja rozwoju zrównoważonego wniosła nowe podejście do zagadnień związanych z rozwojem miejskim, w tym planowania i funkcjonowania przestrzeni publicznej.

\section{Badane miasta średnie regionu łódzkiego}

Na potrzeby prowadzonych badań miasta średnie regionu łódzkiego podzielono na trzy grupy ze względu na liczbę ludności:

- małe miasta średnie 20000 - 30000 mieszkańców ${ }^{1}$,

- średnie miasta średnie 30000 - 50000 mieszkańców,

- duże miasta średnie 50000 - 100000 mieszkańców.

Do poszczególnych grup przyporządkowano następujące miasta:

Małe miasta średnie (20 000 - 30000$):^{2}$

- Ozorków

20136

- Aleksandrów Łódzki

21257

- Opoczno

22100

- Wieluń

23451

- Eowicz

29280

\footnotetext{
${ }^{1}$ Dla przejrzystości zapisu klasyfikacji nie zastosowano podziału liczby ludności na zbiory rozłączne, tj. 20001 - 30000 lub 20000 do 29999.

${ }^{2}$ Liczba mieszkańców wg danych GUS na dzień 30 czerwca 2014 r.
} 
Średnie miasta średnie (30 000 - 50 000):

- Sieradz

- Zduńska Wola

- Kutno

- Radomsko

- Skierniewice
43195

43430

45523

47560

48693

Duże miasta średnie (50 000 - 100 000):

- Zgierz

57458

- Betchatów

59469

- Tomaszów Mazowiecki

64712

- Pabianice

67462

- Piotrków Trybunalski

Do badań jakości przestrzeni publicznej centrum wybrano sześć miast średnich regionu łódzkiego, po dwa z każdej wyodrębnionej grupy wielkościowej. Przy wyborze kierowano się zasadą zestawienia w każdej z grup dwóch miast o innej ścieżce rozwojowej: miasto stare, o wielowiekowej tradycji, bogatej strukturze przestrzennej, zasobach dziedzictwa kulturowego oraz o zróżnicowanej funkcji i miasto nowe, powstałe jako monofunkcyjne, przemysłowe. Grupę miast najmniejszych reprezentują w badaniach Wieluń (miasto stare) i Ozorków (miasto nowe), miasta grupy pośredniej - Radomsko (miasto stare) i Zduńska Wola (miasto nowe) oraz duże miasta średnie - Piotrków Trybunalski (miasto stare) i Bełchatów (miasto nowe).

Badania były wykonywane w latach 2014 i 2015 przez grupy studenckie kierunku Gospodarka Przestrzenna Wydziału Nauk Geograficznych Uniwersytetu Łódzkiego w ramach specjalnościowych ćwiczeń terenowych na I roku studiów stacjonarnych magisterskich.

\section{Rewitalizacja}

Definicja rewitalizacji w Ustawie o rewitalizacji [2015] określa ją jako proces zmierzający do wyprowadzenia ze stanu kryzysowego obszarów zdegradowanych, podkreślając konieczność podjęcia działań całościowych, integrujących działania na rzecz społeczności lokalnej, przestrzeni i gospodarki, skoncentrowanych terytorialnie i prowadzonych we współpracy z lokalną społecznością i innymi interesariuszami rewitalizacji na podstawie programów rewitalizacji. Aspekt społeczny jest podstawowym filarem rewitalizacji: poprawa i osiąganie wysokiej jakości życia mieszkańców jest zasadniczym celem działań rewitalizacyjnych. Rewitalizacja prowadzona jest przede wszystkim dla lokalnej społeczności, zarówno zamieszkującej obszar zdegradowany, jak i pozostałych mieszkańców i użytkowników miasta. Takie ujęcie procesu rewitalizacji, gdzie podstawowym warunkiem jest dążenie do poprawy sytuacji życiowej lokalnej społeczności, jest bardzo ważną zmianą w stosunku do wielu dotychczas realizowanych zamierzeń rewitalizacyjnych w Polsce, które koncentrowały się na tzw. projektach twardych, dotyczących przemian substancji fizycznej miast, w niewielkim stopniu dotykających kwestii społecznych lub gospodarczych. 
Z analiz programów rewitalizacji wykonanych przez Instytut Rozwoju Miast wynika ${ }^{3}$, że we wszystkich zrealizowanych dotychczas programach rewitalizacji w miastach polskich modernizacja infrastruktury technicznej oraz inwestycje związane z odnową przestrzeni publicznej, zlokalizowanej także w centrach miast, odgrywały podstawowe znaczenie.

Stwierdzono, że wynika to z kilku przyczyn:

- Działania na rzecz modernizacji infrastruktury technicznej i przestrzeni publicznej stanowią domenę kompetencji władz samorządowych;

- W tym właśnie obszarze zagadnień inwestycyjnych skumulowały się braki z okresu socjalistycznego;

- Inwestycje w modernizację infrastruktury technicznej otwierają możliwości inwestowania w przyległych nieruchomościach;

- Podjęcie tego typu działań przez władze samorządowe stymuluje lokalną przedsiębiorczość;

- Poprawa stanu zagospodarowania i standardu przestrzeni publicznych przekłada się na podniesienie bezpieczeństwa publicznego oraz wpływa na ograniczenie reakcji społecznie negatywnych;

- Osiągnięty w wyniku działań na rzecz przestrzeni publicznej efekt poprawy wizerunku pozytywnie wpływa zarówno na identyfikację lokalnej społeczności z miejscem zamieszkania, jak i opinię użytkowników z zewnątrz na temat rewitalizowanego obszaru oraz całego miasta [Rewitalizacja polskich miast... 2010, s. 24].

Wszystkie badane miasta średnie w latach 2007-2011 uchwaliły programy rewitalizacji, zostały one wdrożone przez pięć miast - poza Radomskiem.

\section{Metoda oceny jakości przestrzeni publicznej centrum}

Na potrzeby badań jakości przestrzeni publicznej centrum opracowano syntetyczną metodę oceny, składającą się z trzech elementów:

- waloryzacji graficznej,

- waloryzacji tabelarycznej,

- badań kwestionariuszowych [Wojnarowska 2016]4.

Wszystkie wyżej wymienione elementy metody są propozycjami autorskimi, bazującymi na analizie dotychczas stosowanych metod waloryzacji przestrzeni miejskiej w kraju i za granica, a także w programach rewitalizacji dotyczących oceny deficytów i konfliktów w obszarze kryzysowym [Kozłowski i Wojnarowska 2011, s. 34-35]. W celu wyłonienia czynników wpływających na jakość przestrzeni publicznej (lub które powinny na nią wpływać), przeanalizowano współczesne koncepcje i idee dotyczące rozwoju miejskiego: zrównoważone-

\footnotetext{
${ }^{3}$ Tezy wypracowane w ramach projektu badawczego-zamawianego pt. Rewitalizacja miast polskich jako sposób zachowania dziedzictwa materialnego i duchowego oraz czynnik zrównoważonego rozwoju, projekt realizowany przez IRM od czerwca 2007 do czerwca $2010 \mathrm{r}$.

${ }^{4}$ Opis metodologii badań na podstawie autorskiej syntetycznej metody oceny jakości przestrzeni publicznej centrum miasta przedstawiono w artykule zatytułowanym Model for assessment of Public Space Quality in Town Centers zamieszczonym w publikacji ESRAP, 23, 1, 2016, s. 81-109.
} 
go rozwoju, jakości życia, atrakcyjności miasta, jakości miejsca, jakości przestrzeni miejskiej i jakości przestrzeni publicznej. Do wyznaczenia obszaru badań wykorzystano autorską metodę wyznaczenia granic centrum na postawie zasięgu tzw. „kluczowej przestrzeni publicznej” [Wojnarowska 2015]. Opracowana metoda może służyć nie tylko ocenie istniejącej przestrzeni publicznej centrum, może być także użyteczna przy ocenie projektów dotyczących przestrzeni publicznej centrum, a zebrane w wyniku wymienionych wyżej elementów metody, informacje i opinie użytkowników mogą być wykorzystywane przy planowaniu nowych inwestycji i działań w przestrzeni publicznej w przyszłości.

\section{Ryc.1. Mapa waloryzacji graficznej Wielunia}

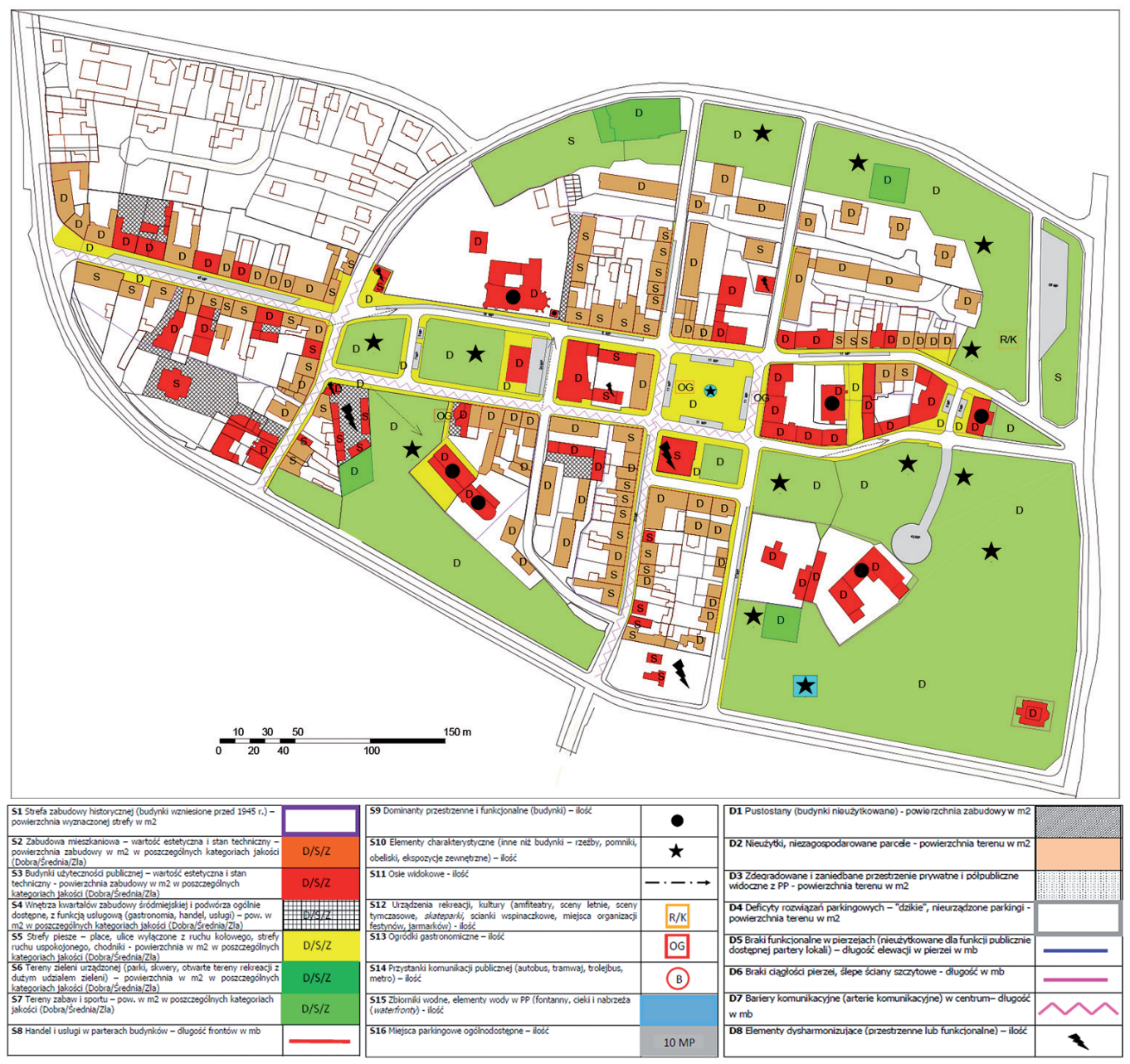

Źródło: opracowanie własne 


\section{Wyniki waloryzacji graficznej}

Waloryzacja graficzna umożliwia zgromadzenie informacji dotyczących obiektywnych i subiektywnych czynników jakości przestrzeni publicznej. Celem waloryzacji graficznej jest z jednej strony uzyskanie wizualnego obrazu sytuacji, który jest czytelny dzięki swej przejrzystej formie graficznej nawet dla nieprzygotowanych profesjonalnie osób, co umożliwia wykorzystanie tego elementu modelu, jako materiału do dyskusji społecznych nad jakością przestrzeni publicznej. Z drugiej strony, po przeliczeniu na wartości liczbowe, waloryzacja graficzna umożliwia uzyskanie syntetycznego wskaźnika jakości przestrzeni publicznej $\mathrm{w}$ postaci indeksu dla danego miasta. W związku z tym umożliwia monitorowanie stanu przestrzeni w mieście - w sensie uzyskiwania porównywalnych danych liczbowych w kolejnych okresach, zarówno dla poszczególnych elementów waloryzacji, jak i dla indeksu całego miasta. Daje też możliwość porównywania jakości przestrzeni publicznej różnych miast, przy zastosowaniu jednorodnej metody oceny. Waloryzacja graficzna ze względu na wymagany zakres wiedzy jest wykonywana przez osoby posiadające wykształcenie kierunkowe związane z planowaniem przestrzennym.

W waloryzacji graficznej wyróżniono dwie grupy czynników rzutujących na ocenę jakości przestrzeni publicznej: czynniki pozytywne (stymulanty) oznaczono symbolami od S1 do S16 oraz czynniki negatywne (destymulanty) z oznaczeniami D1 do D8, przedstawiono na rycinie 1 .

W wyniku opracowania materiału zgromadzonego podczas wizji lokalnej w terenie, utworzono mapy waloryzacji graficznej miast, przy użyciu ustalonych oznaczeń graficznych. Na rycinie 1. przedstawiono przykład mapy waloryzacyjnej Wielunia.

Następnie przeniesiono wyniki pomiarów poszczególnych czynników (wykonane w programie graficznym) do zbiorczej tabeli. Ponieważ wartości liczbowe uzyskane w wyniku obliczeń są różnego rzędu - ilościowe wahają się od jednostek do setek, natomiast liniowe

Tabela 1. Wyniki waloryzacji graficznej dla wybranych miast średnich regionu łódzkiego

\begin{tabular}{|l|c|c|c|c|}
\hline \multicolumn{1}{|c|}{ Miasto } & $\begin{array}{c}\text { Sumaryczny wynik } \\
\text { waloryzacji } \\
\text { graficznej (pkt) }\end{array}$ & $\begin{array}{c}\text { Powierzchnia } \\
\text { centrum (ha) }\end{array}$ & $\begin{array}{c}\text { Indeks waloryzacji } \\
\text { graficznej } \\
\text { (pkt/ha) }\end{array}$ & $\begin{array}{c}\text { Pozycja } \\
\text { w rankingu }\end{array}$ \\
\hline Bełchatów & 72,9 & 9,7 ha & 7,52 & $\mathbf{1}$ \\
\hline Wieluń & 146,9 & 21,2 ha & 5,93 & $\mathbf{2}$ \\
\hline Piotrków Trybunalski & 97,6 & 18,2 ha & 2,36 & $\mathbf{3}$ \\
\hline Ozorków & 22,5 & 8,2 ha & $\mathbf{4}$ \\
\hline Radomsko & 9,0 & 11,6 ha & 0,78 & $\mathbf{5}$ \\
\hline Zduńska Wola & 5,9 & 8,2 ha & 0,72 & $\mathbf{6}$ \\
\hline
\end{tabular}

Źródło: badania własne 


\section{Ryc. 2. Zestawienie wartości wskaźników waloryzacji graficznej dla miast}

\begin{tabular}{|c|c|c|c|c|c|c|c|c|c|c|c|c|c|c|c|c|c|c|c|c|c|c|c|c|c|c|}
\hline \multirow{2}{*}{$\begin{array}{l}\text { OZNACZENIE } \\
\text { GRAFICZNE }\end{array}$} & \multicolumn{16}{|c|}{ STYMULANTY ilość/wartość } & \multicolumn{8}{|c|}{ DESTYMULANTY ilośc/wartośt } & \multirow{2}{*}{$\underset{s}{\operatorname{SuMA}}$} & \multirow{2}{*}{ 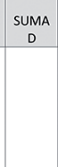 } \\
\hline & & $\frac{N}{n}$ & $\frac{N}{n}$ & @册 & $\frac{N}{0}$ & $\frac{N}{a}$ & & & 0 & $\star$ & $\uparrow$ & $\underset{\varkappa}{\varkappa}$ & 8 & $\infty$ & & $\sum_{0}^{0}$ & & & & & & & & & & \\
\hline OPIS & $\begin{array}{l}\text { STREF } \\
\text { AZAB. } \\
\text { HIST. } \\
\text { POW. } \\
\text { W M2 } \\
\end{array}$ & 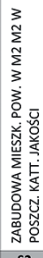 & 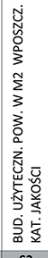 & 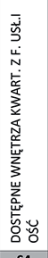 & 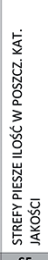 & 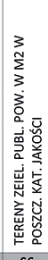 & 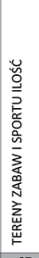 & 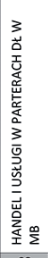 & 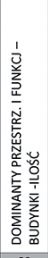 & 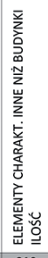 & 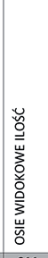 & 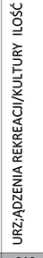 & 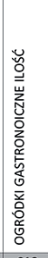 & 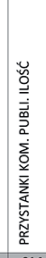 & 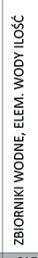 & 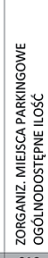 & 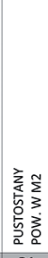 & 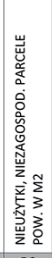 & 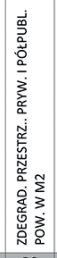 & 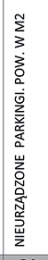 & 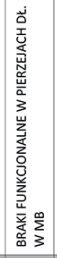 & 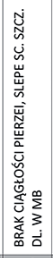 & 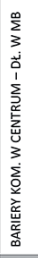 & 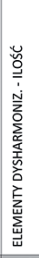 & & \\
\hline & s1 & s2 & $\$ 3$ & 54 & 55 & 56 & 57 & 58 & 59 & 510 & s11 & 512 & S13 & $\$ 14$ & 515 & $\$ 16$ & D1 & D2 & D3 & D4 & D5 & D6 & D7 & D8 & & \\
\hline $\begin{array}{l}\text { WIELUN } \\
146,9 \mathrm{pkt}\end{array}$ & 5,4 & 13 & 12,1 & 11 & 12,8 & 63,3 & 4 & 1,2 & 7 & 12 & 4 & 1 & 3 & 1 & 1 & 3,1 & 0 & 0 & 0 & 0 & 0 & 0 & .1 & -7 & 154,9 & 8 \\
\hline $\begin{array}{l}\text { Ozonków } \\
\text { 22,5 pkt }\end{array}$ & 5,6 & $-2,3$ & 2 & 5 & 9,2 & 0 & 0 & 0,7 & 1 & 2 & 2 & 0 & 0 & 2 & 1 & 1,5 & 0 & $-2,4$ & 0 & 0 & $-0,1$ & $-0,2$ & $.0,5$ & -4 & 29,7 & $-7,2$ \\
\hline $\begin{array}{l}\text { RADOMSKO } \\
9,0 \mathrm{pkt}\end{array}$ & 4,4 & 2,9 & 3,4 & 7 & 1,6 & 2 & 0 & 1,2 & 2 & 5 & 3 & 0 & 1 & 3 & 2 & 1,4 & 0 & $-3,4$ & $-12,1$ & 0 & 0 & $-0,6$ & $-0,8$ & -14 & 39,9 & $-30,9$ \\
\hline $\begin{array}{l}\text { ZDUNSKA } \\
\text { woLA } \\
5,9 \text { pkt }\end{array}$ & 2,7 & 0,1 & 4,6 & 0 & 3 & 3,4 & 0 & 0,5 & 1 & 2 & 3 & 0 & 1 & 2 & 0 & 0,8 & 0 & $-4,5$ & $-0,8$ & $-0,6$ & 0 & $-0,5$ & $-0,8$ & -11 & 24,1 & $-18,2$ \\
\hline $\begin{array}{l}\text { PIOTRKó́w } \\
\text { TRYB. } 97,6\end{array}$ & 10,3 & 10,6 & 16,7 & 7 & 16,5 & 9,9 & 0 & 1,6 & 7 & 5 & 6 & 1 & 13 & 2 & 1 & 1,5 & 2,9 & 0 & $-4,3$ & 0 & \begin{tabular}{|l|l} 
& $-0,4$
\end{tabular} & 0,2 & $-0,7$ & -3 & 109,1 & $-11,5$ \\
\hline $\begin{array}{l}\text { BEECHATÓW } \\
72,9 \mathrm{pkt}\end{array}$ & 2 & 1,8 & 18,2 & 7 & 16,9 & 3,5 & 1 & 0,2 & 6 & 3 & 3 & 1 & 7 & 2 & 2 & 2,5 & $-0,1$ & 0 & \begin{tabular}{|l|l|} 
& $-0,5$ \\
\end{tabular} & 0 & 0 & 0 & $\begin{array}{l}-0,6 \\
\end{array}$ & -3 & 77,1 & $-4,2$ \\
\hline
\end{tabular}

Źródło: opracowanie własne

i powierzchniowe wyrażają się w tysiącach, dziesiątkach i setkach tysięcy jednostek (metrów bieżących i metrów kwadratowych), w celu uzyskania wartości podobnego rzędu dla poszczególnych czynników zastosowano przeliczenie na wskaźniki zgodnie z ustalonymi zasadami [Wojnarowska 2016, s. 97], dla uzyskania w rezultacie ich zsumowania indeksu dla danego miasta. Wyniki przeliczenia wartości liczbowych poszczególnych czynników na wskaźniki przedstawiono na rycinie 2.

Dla uzyskania wskaźnika syntetycznego dla każdego miasta, czyli indeksu, wynik sumaryczny wskaźników dotyczących każdego miasta (sumę wartości stymulant i destymulant) podzielono przez powierzchnię zdelimitowanego centrum wyrażoną w hektarach. Zabieg taki był konieczny w celu uzyskania porównywalnych wyników dla poszczególnych miast, ze względu na znaczne rozbieżności w wielkości powierzchni centrum. W tabeli 1. zamieszczono wyniki rankingu waloryzacji graficznej dla wybranych miast średnich regionu łódzkiego.

Stwierdzić należy, że pomiędzy analizowanymi miastami istnieją znaczące dysproporcje w jakości przestrzeni publicznej centrum w ramach waloryzacji graficznej. O ile wyniki miast zajmujących trzy pierwsze lokaty: Bełchatowa, Wielunia i Piotrkowa Trybunalskiego są zbliżone, to Ozorków znajdujący się na miejscu czwartym osiągnął zaledwie połowę war- 
tości indeksu dla Piotrkowa Trybunalskiego, natomiast Radomsko i Zduńska Wola rezultaty niemal czterokrotnie niższy od Ozorkowa.

\section{Wyniki waloryzacji tabelarycznej}

Drugim elementem metody oceny jakości przestrzeni publicznej jest waloryzacja tabelaryczna. Zakres waloryzacji, podział na obszary i proponowane kryteria oceny, wynikają z syntezy proponowanych dotychczas metod oraz własnych propozycji autorki, na bazie wniosków wyciągniętych z przeglądu koncepcji ważnych dla kształtowania i oceny jakości przestrzeni publicznej. Jej formę oparto na propozycji J. Natland [2007] oceny jakości przestrzeni publicznej ulicy handlowej w New Westminster w USA.

W waloryzacji tabelarycznej zaproponowano zgrupowanie kryteriów w sześciu obszarach zagadnień:

- K: kompozycja / czytelność / wizerunek / charakter / ciągłość i domknięcie,

- W: witalność /elastyczność / łatwość adaptacji / użytkowanie i aktywności / różnorodność,

- P: komfort / spełnianie potrzeb / wygoda,

- D: dostępność / powiązania / łatwość przemieszczania się,

- B: bezpieczeństwo / kontrola,

- ZR: spełnianie założeń zrównoważonego rozwoju.

W każdym z obszarów ujęto 7 czynników do oceny, które po nadaniu im punktacji według założonego systemu oceny, uzyskują charakter wskaźników. Każdy czynnik/kryterium może uzyskać od 0 do 5 punktów - zgodnie ze sposobem oceny przyjętym w tabeli 2., w zależności od stopnia spełniania poszczególnych kryteriów [Wojnarowska 2016, s. 100-104]. Taki system oceny był już stosowany w waloryzacjach przestrzeni publicznej, w tym w Poznaniu.

Tabela 2. Ranking miast na podstawie wyników metody tabelarycznej

\begin{tabular}{|l|c|c|c|c|}
\hline \multicolumn{1}{|c|}{ Miasto } & $\begin{array}{c}\text { Suma wyników } \\
\text { uzyskanych } \\
\text { w poszczególnych } \\
\text { obszarach waloryzacji (\%) }\end{array}$ & $\begin{array}{c}\text { Maksymalna } \\
\text { punktacja } \\
\text { w sześciu } \\
\text { obszarach (\%) }\end{array}$ & Indeks & $\begin{array}{c}\text { Pozycja } \\
\text { w rankingu }\end{array}$ \\
\hline Bełchatów & 428,13 & 600 & 0,71 & $\mathbf{1}$ \\
\hline Wieluń & 400,31 & 600 & 0,67 & $\mathbf{2}$ \\
\hline Piotrków Trybunalski & 359,61 & 600 & 0,60 & $\mathbf{3}$ \\
\hline Zduńska Wola & 317,98 & 600 & 0,53 & $\mathbf{4}$ \\
\hline Ozorków & 313.21 & 600 & 0,52 & $\mathbf{5}$ \\
\hline Radomsko & 266,76 & 600 & 0,44 & $\mathbf{6}$ \\
\hline
\end{tabular}

Źródło: badania własne 
Skrajnie niska ocena dotyczy całkowitego braku spełniania kryterium, ocena najwyższa - doskonałego stopnia spełniania kryterium [Natland 2007; Cegłowska i Matykowski 2010]. Maksymalna liczba punktów uzyskanych w ramach jednego obszaru wynosi w związku z tym 35 .

Wartości uzyskanej przez miasta punktacji w poszczególnych obszarach waloryzacji przedstawiono w postaci procentowej, pokazującej stosunek uzyskanej punktacji do maksymalnej. Na bazie osiągniętych przez miasta sumarycznych rezultatów obliczono indeks waloryzacji tabelarycznej - jako proporcję sumy punktów uzyskanych w wymienionych obszarach ewaluacji do maksymalnego możliwego do osiągnięcia wyniku, który wynosił 600\% (sześć obszarów ewaluacji po 100\%) (tabela 2).

Także waloryzacja tabelaryczna jest opracowywana przez specjalistów. Umożliwia ona uzyskanie informacji o obiektywnych cechach jakości przestrzeni publicznej centrum. Również w waloryzacji tabelarycznej trzy pierwsze lokaty zostały przyznane tym samym miastom, co w waloryzacji tabelarycznej, potwierdzając ocenę tych miast w opinii ekspertów.

\section{Wyniki badań kwestionariuszowych}

Zastosowanie badań kwestionariuszowych umożliwia uzyskanie oceny jakości przestrzeni publicznej, dokonywanej przez użytkowników przestrzeni niebędących osobami o wykształceniu kierunkowym związanym z kształtowaniem przestrzeni. $W$ ich ramach uzyskujemy informacje na temat subiektywnej oceny jakości przestrzeni publicznej centrum miasta. Ponadto, w ramach waloryzacji tabelarycznej oraz waloryzacji graficznej dokonuje się oceny istniejących elementów zagospodarowania przestrzeni, nie są w związku z tym wykazywane te elementy, których w nich brakuje. Badania kwestionariuszowe uzupełniają tę lukę, dając możliwość zgłoszenia uwag dotyczących braków oraz sugestii zmian przez użytkowników.

Pytania w kwestionariuszu zostały sformułowane jako wielokrotnego wyboru - o charakterze koniunktywnym (odpowiedzi nie wykluczają się wzajemnie, można więc wybrać więcej niż jedną), co dawało ankietowanym możliwość wskazania wielu odpowiedzi - zarówno w zakresie elementów istniejącego, jak i planowanego zagospodarowania. Pytania miały charakter otwarty - w każdym z pytań pozostawiono możliwość wskazania przez respondenta innych elementów, niż ujęte w formularzu.

Ze względu na różną liczbę studentów w kolejnych latach ćwiczeń terenowych badaniom została poddana różna liczba respondentów w obu miastach, w związku z tym wyniki badań przedstawiono w formie procentowej, odzwierciedlającej procentowy udział głosów oddanych na daną odpowiedź w stosunku do ogólnej liczby respondentów w danym mieście.

Druga część kwestionariusza dotyczyła ustalenia oceny w oczach użytkowników wybranych zasadniczych cech przestrzeni publicznej, jak: dostępność różnymi środkami transportu, estetyka, bezpieczeństwo, czystość oraz organizacja różnego rodzaju imprez. Suma 
Tabela 3. Zestawienie sumy pozytywnych odpowiedzi dotyczących wybranych cech przestrzeni publicznej centrum

\begin{tabular}{|c|c|c|c|c|c|c|}
\hline & $\begin{array}{c}\text { Wieluń } \\
(\%)\end{array}$ & $\begin{array}{c}\text { Ozorków } \\
\text { (\%) }\end{array}$ & $\begin{array}{c}\text { Radomsko } \\
(\%)\end{array}$ & $\begin{array}{c}\text { Zduńska } \\
\text { Wola } \\
(\%)\end{array}$ & $\begin{array}{c}\text { Piotrków } \\
\text { Trybunalski } \\
(\%)\end{array}$ & $\begin{array}{c}\text { Bełchatów } \\
(\%)\end{array}$ \\
\hline $\begin{array}{l}\text { Dostępność } \\
\text { piesza }\end{array}$ & 99 & 78 & 98 & 94 & 95 & 86 \\
\hline $\begin{array}{l}\text { Dostępność } \\
\text { rowerem }\end{array}$ & 88 & 50 & 80 & 84 & 59 & 82 \\
\hline $\begin{array}{l}\text { Dostępność } \\
\text { samochodem }\end{array}$ & 81 & 85 & 73 & 98 & 86 & 73 \\
\hline $\begin{array}{l}\text { Dostępność } \\
\text { transportem } \\
\text { publicznym }\end{array}$ & 92 & 61 & 66 & 89 & 81 & 56 \\
\hline Estetyka & 100 & 75 & 79 & 87 & 91 & 89 \\
\hline Bezpieczeństwo & 98 & 66 & 86 & 94 & 94 & 88 \\
\hline Czystość & 100 & 56 & 76 & 83 & 81 & 96 \\
\hline $\begin{array}{l}\text { Organizowane } \\
\text { atrakcje }\end{array}$ & 75 & 16 & 74 & 82 & 46 & 69 \\
\hline Razem & 733 & 489 & 632 & 711 & 633 & 639 \\
\hline $\begin{array}{l}\text { Odsetek pozytyw- } \\
\text { nych odpowiedzi }\end{array}$ & 91,6 & 61,1 & 79,0 & 88,9 & 79,1 & 79,9 \\
\hline $\begin{array}{l}\text { Pozycja } \\
\text { w rankingu }\end{array}$ & 1 & 6 & 5 & 2 & 4 & 3 \\
\hline
\end{tabular}

Źródło: badania własne

pozytywnych (tj. nie negatywnych - bardzo dobrych, dobrych i zadowalajacych) odpowiedzi przedstawiona jest $\mathrm{w}$ tabeli 3.

W tym elemencie syntetycznej metody oceny jakości przestrzeni publicznej dwa z trzech przodujących miast w waloryzacji graficznej i tabelarycznej także zajęły dwie pierwsze lokaty: Wieluń i Bełchatów (tablela 4), Piotrków Trybunalski zajął zamiast trzeciej - czwartą pozycję (tabela 3). Wśród miast zajmujących pierwsze pozycje w rankingu w dość niespodziewany sposób znalazła się Zduńska Wola, zajmując drugie miejsce (tabela 3). Trzeba w tym miejscu przypomnieć, że w badaniach kwestionariuszowych wykazano opinie użytkowników miast, prezentujące subiektywne oceny jakości przestrzeni publicznej. Wskazuje to na fakt, iż Zduńska Wola została oceniona bardzo wysoko przez osoby niebędące specjalistami, pomimo obecności wielu niedogodności w przestrzeni publicznej, które zaważyły na znacznie niższej ocenie ekspertów w dwóch poprzednich elementach metody oceny. 


\section{Wnioski}

Na bazie trzech elementów cząstkowych (ranking miast w waloryzacji graficznej, tabelarycznej i badaniach kwestionariuszowych) dokonano sumarycznego rankingu miast w ramach metody oceny jakości przestrzeni publicznej centrum (tabela 4).

Obserwując wyniki oceny w ramach całej metody, trzeba zauważyć bardzo wysoką drugą pozycję Wielunia i Bełchatowa, które osiągnęły równą liczbę punktów. W ostatecznej ocenie Bełchatów zajął pierwsze miejsce, ponieważ pomimo tej samej punktacji, dwukrotnie zajął pierwsze miejsce w metodach cząstkowych - w waloryzacji graficznej i tabelarycznej.

Ostateczne rezultaty rankingu zostały przeanalizowane pod kątem różnorodnych kryteriów, charakteryzujących zarówno miasto jako całość, jak i jego centrum:

1. Kryterium wieku miasta - miasto stare lub nowe;

2. Kryterium wielkości miasta - liczba mieszkańców;

3. Kryterium odległości miasta od stolicy regionu - Łodzi;

4. Kryterium wielkości zdelimitowanego centrum;

5. Kryterium wielkości strefy historycznej w centrum;

6. Kryterium wielkości terenów zielonych w centrum;

7. Kryterium rewitalizacji centrum - czy została przeprowadzona i w jakim zakresie.

Podsumowując analizę wyników rankingu miast na podstawie przyjętych wyżej 7 kryteriów można stwierdzić, że pierwsza pozycja Bełchatowa w rankingu finalnym, jak i dwóch cząstkowych (waloryzacji graficznej i tabelarycznej) sugeruje, że dla jakości przestrzeni publicznej centrum miasta nie ma znaczenia pięć pierwszych z sześciu kryteriów, które mają

Tabela 4. Zestawienie pozycji miast w ocenie za pomocą trzech elementów metody oraz ostatecznego rankingu w zakresie jakości przestrzeni publicznej centrum

\begin{tabular}{|l|r|r|r|r|r|r|}
\hline & Wieluń & Ozorków & Radomsko & $\begin{array}{c}\text { Zduńska } \\
\text { Wola }\end{array}$ & $\begin{array}{c}\text { Piotrków } \\
\text { Trybunalski }\end{array}$ & Bełchatów \\
\hline $\begin{array}{l}\text { Miejsce w waloryzacji } \\
\text { graficznej }\end{array}$ & 2 & 4 & 5 & 6 & 3 & 1 \\
\hline $\begin{array}{l}\text { Pozycja w waloryzacji } \\
\text { tabelarycznej }\end{array}$ & 2 & 5 & 6 & 4 & 3 & 1 \\
\hline $\begin{array}{l}\text { Pozycja w drugiej } \\
\text { części badań kwestio- } \\
\text { nariuszowych }\end{array}$ & 1 & 6 & 5 & 2 & 4 & 3 \\
\hline Suma & 5 & 15 & 16 & 12 & 10 & 5 \\
\hline $\begin{array}{l}\text { Ostateczna pozycja } \\
\text { w rankingu }\end{array}$ & $\mathbf{2}$ & $\mathbf{5}$ & $\mathbf{6}$ & $\mathbf{4}$ & $\mathbf{3}$ & $\mathbf{1}$ \\
\hline
\end{tabular}

Źródło: badania własne 
charakter ilościowy. Bełchatów nie jest miastem starym, jego strefa historyczna jest najmniejsza pośród wszystkich badanych miast, tak jak i wielkość terenów zielonych w centrum, także wielkość zdelimitowanego centrum nie należy do dużych, lokując się w środku badanej grupy miast. To samo dotyczy lokalizacji względem Łodzi - jest ona przeciętna, Bełchatów usytuowany jest w średniej odległości od miasta centralnego regionu. Spośród pierwszych sześciu kryteriów, jedynie wielkość miasta może być istotna - Bełchatów należy do grupy dużych miast średnich, liczących ponad 50000 mieszkańców, podobnie jak Piotrków Trybunalski, który zajął trzecią lokatę.

Analiza pod kątem przyjętych kryteriów wskazuje natomiast na zasadnicze znaczenie dla oceny jakości przestrzeni publicznej centrum kryterium siódmego, o charakterze jakościowym - zrealizowanej z sukcesem, szeroko zakrojonej rewitalizacji centrum. Dobrze zaprogramowany i zrealizowany program rewitalizacji prowadzi do poprawy jakości przestrzeni publicznej w wielu aspektach, zarówno w odniesieniu do zagospodarowania, jak i funkcji: wartości użytkowych, dostosowania do potrzeb osób pieszych, dostępności różnymi środkami transportu, przenikalności (permeability) obszaru dla ruchu pieszego i rowerowego, stopnia zaspokajania potrzeb, witalności oraz bezpieczeństwa, czyli w zasadzie wszystkich zasadniczych obszarów oceny jakości przestrzeni publicznej. Jedynie w odniesieniu do realizacji założeń rozwoju zrównoważonego możemy mówić o niewielkich często rezultatach, aczkolwiek i w tym zakresie, jeśli proces rewitalizacji jest zaplanowany z uwzględnieniem takich też aspektów, ocena w tym zakresie jest wyższa niż w innych miastach (w Bełchatowie, Wieluniu i Zduńskiej Woli wyniki waloryzacji tabelarycznej w tym aspekcie były najwyższe). Znaczenie rewitalizacji centrum dla jakości przestrzeni publicznej, przede wszystkim też jej społecznego odbioru potwierdza druga pozycja Zduńskiej Woli w badaniach kwestionariuszowych.

Biorąc pod uwagę rewitalizację centrum, można zatem stwierdzić, że jest to istotne kryterium wpływające na wysoką jakość przestrzeni publicznej centrum. Z sześciu analizowanych miast jedynie Radomsko nie zrealizowało w ostatnich latach szerzej zakrojonego programu rewitalizacji centrum i jest ono ocenione najniżej z wszystkich miast, zajmując ostatnią pozycję w rankingu ostatecznym, w cząstkowych - dwa razy piątą i raz szóstą. Zajmujące dwie pierwsze lokaty Bełchatów i Wieluń zrealizowały w ostatnich latach duże programy rewitalizacji stref centralnych miasta, za które Bełchatów został nagrodzony nagrodą Towarzystwa Urbanistów Polskich w skali kraju, a Wieluń i Zduńska Wola - w skali regionu.

Możemy zatem stwierdzić, że rewitalizacja centrum może w znaczący sposób pozytywnie wpłynąć na jakość zlokalizowanej tam przestrzeni publicznej, ale pod pewnymi warunkami. Program rewitalizacji musi uwzględniać potrzeby użytkowników oraz opinie dotyczące obecnego i przyszłego zagospodarowania tej przestrzeni, a przede wszystkim braków w funkcjach i oferowanych atrakcjach. Obecnie wskazywane braki często nadal dotyczą całkiem podstawowych elementów małej architektury oraz potrzeby stworzenia bogatszej oferty rekreacyjnej i zróżnicowanych możliwości spędzania wolnego czasu, w tym w postaci aktywności fizycznej. Nie można zatem poprzestać jedynie na poprawie walorów estetycznych czy użytkowych przestrzeni publicznej, chociaż mają one fundamentalne znaczenie, ale 
należy dążyć do wzmocnienia witalności centrum poprzez tworzenie możliwości realizacji różnorodnych aktywności i wzmacniania oferty funkcjonalnej.

\section{Bibliografia}

CABE (Commission for Architecture and the Built Environment), 2004, The value of public space, London.

European Council of Spatial Planners, 2005, Guide to Sustainable Development at the Local Level: 'Try It this Way'.

Carmona M., Sieh L. 2004, Measuring Quality in planning. Managing the performance process, Spon Press, London and New York.

Castells M., 1982, Kwestia miejska, PWN, Warszawa.

Cegłowska A., Matykowski R., 2010, Przestrzenie publiczne i ich znaczenie w dużym mieście: przypadek Poznania, [w:] „Studia miejskie”: Funkcje miast jako czynnik kształtowania przestrzeni miejskiej, 2, Opole, s. 219-230.

Chmielewski J.M., 2001, Teoria urbanistyki w projektowaniu i planowaniu miast, Oficyna Wydawnicza Politechniki Warszawskiej, Warszawa.

Crowe T.D., 2000, Crime Prevention Through Environmental Design: Applications of Architectural Design and Space Management Concepts, National Crime Prevention Institute, University of Louisville.

Gehl J., 2013, Życie między budynkami. Użytkowanie przestrzeni publicznych, Kraków.

Gruszecka K., Gzell S., Rembarz G., 2009, Osiedle: reurbanizacja, „Urbanista”, 10, 181.

Jacobs J., 1961, The Death and Life of Great American Cities, Vintage Books, Random House, Inc, New York.

Juchnowicz S., 1965, Metoda wyznaczania zasięgu obszaru centrów miejskich. Niektóre problemy ich struktury funkcjonalno-przestrzennej, Warszawa.

Górka Z., 1986, Śródmiejskie ośrodki ustugowe wybranych miast Polski południowej, Uniwersytet Jagielloński, Kraków.

Karta Przestrzeni Publicznej, 2009, III Kongres Urbanistyki Polskiej, 4-5 września, Poznań.

Kozłowski S., Wojnarowska A., 2011, Rewitalizacja zdegradowanych obszarów miejskich. Zagadnienia teoretyczne, Łódź.

Lokalny Program Rewitalizacji Wybranych Obszarów Miejskich i Poprzemysłowych Miasta Radomsko, 2009.

Lokalny Program Rewitalizacji Miasta Wielunia na lata 2007-2013, 2007. 
Lokalny Program Rewitalizacji Bełchatowa na lata 2009-2015, 2009.

Lokalny Program Rewitalizacji obszaru miejskiego Zduńska Wola 2006-2013. Aktualizacja, 2010.

Lokalny Program Rewitalizacji Miasta Wielunia na lata 2007-2013, 2011.

Lorens P., 2006, Tematyzacja przestrzeni publicznej miasta, Wydawnictwo Politechniki Gdańskiej, Gdańsk.

Lorens P., 2007, Tematyzacja przestrzeni publicznej jako wyraz dywersyfikacji struktury urbanistycznej miasta doby globalizacji, [w:] M. Madurowicz (red.), Percepcja wspótczesnej przestrzeni miejskiej, Wyd. WGiSR UW, Warszawa, s. 83-92.

Lynch K., 1984, Good City Form, Massachusetts Institute of Technology, Massachusetts.

Maik W., 2011, Przestrzeń publiczna w mieście: pojęcie, ujęcia badawcze, funkcje i ewolucja zjawiska, [w:] I. Jażdżewska (red.), Przestrzeń publiczna miast, XXIV Konwersatorium Wiedzy o Mieście, Łódź, s. 9-14.

Maliszowa B., 1974, Śródmieście. Wybrane zagadnienia planowania, Arkady, Warszawa.

Mierzejewska L., 2011, Przestrzeń publiczna strefy podmiejskiej (na przykładzie Poznania), [w:] M. Wdowicka i L. Mierzejewska (red.), Problemy rozwoju lokalnego i regionalnego na poczatku XXI wieku, Biuletyn Instytutu Geografii Społeczno-Ekonomicznej i Gospodarki Przestrzennej Uniwersytetu im. A. Mickiewicza w Poznaniu, Seria: „Rozwój Regionalny i Polityka Regionalna", 15, Poznań, s. 85-97.

Natland J., 2007, Urban by Design: An Evaluation of Public Spaces in Downtown New Westminster, Simon Fraser University.

Nowakowski M., 1976, Komunikacja a ksztattowanie centrum miasta, Arkady, Warszawa.

Nowakowski M., 1990, Centrum miasta, Arkady, Warszawa.

Parysek J., Guarino E., Mierzejewska L., 1995, Wybrane problemy teoretyczno-metodologiczne delimitacji centrum miasta, [w:] J. Kaczmarek (red.), Centra i peryferie dużych miast, transformacja i przyszłość. Pojęcia i metody badawcze, VIII Konwersatorium Wiedzy o Mieście, Łódź.

Piotrków Trybunalski Lokalny Program Rewitalizacji na lata 2007-2013, 2009.

Rewitalizacja polskich miast jako sposób zachowania dziedzictwa materialnego $i$ duchowego oraz czynnik zrównoważonego rozwoju. Podsumowanie projektu, 2010, Seria: „Rewitalizacja Miast Polskich", Instytut Rozwoju Miast, Kraków.

Szewczyk P., 2009, Rozwinięcia przestrzeni publicznej w głąb obiektów architektury - nowe miejsca na styku budynku i miasta, rozprawa doktorska, promotor dr hab. inż. arch. L. Nyka, Politechnika Gdańska, Gdańsk.

Ustawa o rewitalizacji z dnia 9 października $2015 \mathrm{r}$.

Wallis A., 1977, Miasto i przestrzeń, PWN, Warszawa. 
Wallis A., 1979, Informacja i gwar - o miejskim centrum, PIW, Warszawa.

Wejchert K., 1984, Elementy kompozycji urbanistycznej, Arkady, Warszawa.

Whyte W.H., 1988, City: Rediscovering the Center.

Wojnarowska A., 2011, Rewitalizacja zdegradowanych obszarów miejskich. Przykłady praktyczne, Łódź.

Wojnarowska A., 2015, Przestrzeń publiczna Uniejowa, [w:] E. Kobojek (red.), „Biuletyn Uniejowski", 4, s. 25-44.

Wojnarowska A., 2016, Model for assessment of Public Space Quality in Town Centers, ESRAP, 23, 1, s. 81-109.

Wolaniuk A., 2008, Centra miast, [w:] S. Liszewski (red.), Geografia urbanistyczna, Łódź, s. 303-342.

\footnotetext{
Urban regeneration and the quality of public space of town center
}

\section{ABSTRACT}

The goal of this article is presentation of research results led on the basis of author's method of assessment of quality of public space. The research revealed the connection between the quality of public space of town center and the revitalization process of this area. The quality of urban space has in our times important meaning as well for the quality of life of inhabitants as for the attractiveness of town for investors and other outer users. Public space conceived as an open space of common accessibility constitutes the element of urban system, fulfilling different functions, being also an important element of town's identity, creating its image and standing for a strong factor of identification for inhabitants. Due to the important role of public space, especially this located in town center, its quality is of fundamental role. In order to determine the quality of public space of town center, the method of assessment was elaborated, consisting of three elements: graphic valorization, checklist valorization and surveys of users' opinions. This method enables the evaluation of quality of the existent public space, but it also can be a helpful instrument in process of designing of public space and programming the investments and events in the future. Revitalization of public space of town center can be an important instrument of improvement of its quality, but only in case of the properly programmed revitalization process, taking under consideration essential factors of quality of public space, influencing: vitality, fulfillment of needs, accessibility, composition and legibility, public safety and coherence with rules of sustainable development. Research led in six middle-sized towns of Łódź region revealed the relation between the high quality of public space and the revitalization of town center.

dr inż. arch. Anna Wojnarowska, specjalizuje się w rewitalizacji, planowaniu przestrzeni miejskiej / specialization in urban regeneration, urban planning. Institute of the Built Environment and Spatial Policy; kontakt/contact: Instytut Zagospodarowania Środowiska i Polityki Przestrzennej, Wydział Nauk Geograficznych, Uniwersytet Łódzki, ul. Kopcińskiego 31, 90-142 Łódź, Polska, email: annawojnarowska.gp@gmail.com 